\title{
KORELASI HIGIENE PRIBADI DAN SANITASI LINGKUNGAN DENGAN KEJADIAN HELMINTHIASIS DI KELURAHAN RAPPOCINI
}

\author{
Nurul Ni’ma Azis ${ }^{1)}$ Andi Fatmawati Muharram ${ }^{2)}$, Fitriyani1) \\ Akademi Analis Kesehatan Muhammadiyah Makassar \\ Alamat Korespondensi.enenima03@gmail.com
}

\begin{abstract}
Abstrak
Helminthiasis (kecacingan) menurut World Health Organization (WHO) adalah infestasi satu atau lebih cacing parasit usus yang terdiri dari golongan nematoda usus. Sebagian besar dari nematode ini adalah penyebab masalah kesehatan masyarakat di dunia. Nematoda golongan STH yang penting dan menginfeksi manusia adalah Ascaris lumbricoides, Necator amaericanus, Ancylostoma dudonelae, Trichuris trichuira dan Strongiloides stercoralis. Infeksi Soil Transmitted Helmiths (STH) masih merupakan endemik di banyak daerah di dunia, terutama di negara yang sedang berkembang dengan sanitasi lingkungan dan kebersihan diri yang sangat kurang. Diperkirakan sekitar 807 juta manusia di dunia terinfeksi Ascaris lumbricoides, sekitar 604 juta menderita trikuriasis dan hookworm (A.duodenale dan N. americanus) menginfeksi sekitar 576 juta manusia di seluruh dunia. Jumlah infeksi STH sangat banyak di Asia Tenggara termasuk Indonesia, Letak geografis Indonesia yang beriklim tropis sesuai untuk perkembangan parasit. Adapun prevalensi kecacingan STH di Indonesia berkisar 40-60\% dan masih merupakan masalah kesehatan masyarakat yang penting (Akhsin, 2011). Prevalensi tertinggi terdapat di Papua dan Sumatera Utara dengan prevalensi antara 50\% hingga 80\%. Tingginya prevalensi ini sangat didukung oleh keadaan alam yang cocok, higiene perorangan dan sanitasi lingkungan yang rendah, pengetahuan dan kurangnya penyuluhan kesehatan. Tujuan dari penelitian ini adalah untuk menganalisis korelasi higiene pribadi dan sanitasi lingkungan dengan kejadian helminthiasis di Kelurahan Rappocini. Metode yang digunakan adalah penelitian deskriptif analitik dengan pendekatan cross sectional dengan metode pemeriksaan sedimentasi. Hasil analisis korelasi korelasi mengahsilkan adanya korelasi higiene pribadi dan sanitasi lingkungan dengan kejadian helminthiasi di kelurahan rappocini. Hal ini berdasarkan uji korelasi nilai $\mathrm{p}(0.00)<0.05$.
\end{abstract}

Kata Kunci: Hiegene pribadi, Sanitasi lingkungan, Helminthiasis

\section{PENDAHULUAN}

Helminthiasis

(kecacingan)

menurut World Health Organization (WHO) adalah infestasi satu atau lebih cacing parasit usus yang terdiri dari golongan nematode usus. Nematoda usus yang ditularkan melalui tanah disebut dengan Soil Transmitted Helminths(STH). Penyebab helmintiasis adalah cacing dari nematoda intestinal yang berhabitat di pencernaan manusia maupun hewan. Sebagian besar dari nematode ini adalah penyebab masalah kesehatan masyarakat di dunia. Nematoda golongan STH yang penting dan menginfeksi manusia adalah Ascaris lumbricoides, Necator amaericanus, Ancylostoma dudonelae, Trichuris trichuira dan Strongiloides stercoralis. Infeksi oleh STH terjadi karena tertelannya telur cacing infektif dari tanah yang terkontaminasi atau larva aktif yang ada di dalam tanah melalui kulit(Safar, 2009).

Infeksi Soil Transmitted Helmiths (STH) masih merupakan endemik di banyak daerah di dunia, terutama di negara yang sedang berkembang dengan sanitasi lingkungan dan kebersihan diri yang sangat kurang. STH yang paling sering menginfeksi manusia adalah Ascaris lumbricoides, Trichuris trichiura, dan hookworn. Diperkirakan sekitar 807 juta manusia di dunia terinfeksi Ascaris lumbricoides, sekitar 604 juta menderita trikuriasis dan hookworm (A.duodenale dan $N$. americanus) menginfeksi sekitar 576 juta manusia di seluruh dunia.

Jumlah infeksi STH sangat banyak di Asia Tenggara termasuk Indonesia, Letak geografis Indonesia yang beriklim tropis sesuai untuk perkembangan parasit. Geographical Information System (GIS) 
menyatakan distribusi STH di Indonesia mencakup seluruh pulau yang ada di Indonesia. Adapun prevalensi kecacingan STH di Indonesia berkisar 40-60\% dan masih merupakan masalah kesehatan masyarakat yang penting (Akhsin, 2011). Prevalensi tertinggi terdapat di Papua dan Sumatera Utara dengan prevalensi antara $50 \%$ hingga $80 \%$.

Tingginya prevalensi ini sangat didukung oleh keadaan alam yang cocok, higiene perorangan dan sanitasi lingkungan yang rendah, pengetahuan dan kurangnya penyuluhan kesehatan. Berbagai jenis cacing usus masih merupakan masalah kesehatan masyarakat dan sering dijumpai baik di kota maupun di desa di Indonesia, seperti cacing gelang (Ascaris lumbricoides), cacing cambuk (Trichuris trichiura) dan cacing tambang (Hookworm) yang dapat mengakibatkan anemia, gangguan gizi, gangguan pertumbuhan dan gangguan kecerdasan. Akan tetapi oleh karena infeksi yang terjadi sering tanpa gejala, sehingga penyakit ini dianggap bukanlah merupakan penyakit yang berbahaya.

Tinggi rendahnya frekuensi kecacingan berhubungan erat dengan kebersihan pribadi dan sanitasi lingkungan. Pencemaran tanah merupakan penyebab terjadinya transmisi telur cacing dari tanah kepada manusia melalui tangan atau kuku yang mengandung telur cacing, lalu masuk ke mulut bersama makanan Angka prevalensi dan intensitas infeksi biasanya paling tinggi pada anak antara usia 3 dan 8 tahun. Penyakit cacingan tersebar luas, baik di perdesaan maupun di perkotaan. Angka infeksi tinggi, tetapi intensitas infeksi (jumlah cacing dalam perut) berbeda. Hasil Survei Cacingan di Sekolah Dasar di beberapa Provinsi pada tahun 1986-1991 menunjukkan prevalensi sekitar $60 \%$ - 80\%, sedangkan untuk semua umur berkisar antara $40 \%-60 \%$. Hasil Survei Subdit Diare pada tahun 2002 dan 2003 pada 40 SD di 10 provinsi menunjukkan prevalensi berkisar antara $2,2 \%-96,3 \%$.

Ringan dan beratnya infeksi kecacingan sangat mempengaruhi kondisi tubuh, keadaan gizi penderita, zat besi dan yang paling serius adalah mampu mempengaruhi mental dan tingkat intelegensi dari penderita dalam hal ini anak-anak. Dengan demikian infeksi STH mampu mempengaruhi kognitif dan perkembangan anak. STH mampu membuat kualitas hidup penderita turun secara drastis karena dapat menurunkan kondisi kesehatan dan produktivitas penderita sehingga secara ekonomi dapat menyebabkan kerugian. Selain itu, dapat menyebabkan kehilangan karbohidrat dan protein sehingga menurunkan kualitas SDM. Pada infeksi berat pada anak-anak dapat menyebabkan gangguan pertumbuhan, penyerapan protein dan malnutrisi. Berdasarkan data dari Dinas Kesehatan Kota Makassar bahwa prevalensi angka kecacingan dengan kejadian diare tahun 2014 adalah sebanyak 28.543 jiwa.

Menurut Hidayat Santoso (2004) bahwa penyakit cacingan terkait dengan perilaku hidup bersih dan sehat serta sanitasi lingkungan. Perilaku merupakan faktor terbesar kedua setelah faktor lingkungan yang mempengaruhi kejadian cacingan (Soekidjo Notoatmodjo, 2003:12). Kejadian cacingan dipengaruhi oleh pengetahuan, sikap, dan praktik tentang hidup sehat (Sekartini dkk, 2002).

Berdasarkan uraian di atas maka penulis akan melakukan penelitian untuk mengetahui sejauh manakah korelasi higiene pribadi dan sanitasi lingkungan dengan kejadian helminthiasis di Kelurahan Rappocini.

\section{METODE PENELITIAN}

\section{Alat dan Bahan}

Alat yang digunakan adalah bekaer gelas, tabung sentrifus, objek gelas, deck gelas, batang pengaduk, sentrifus dan mikroskop. Adapun bahan yang digunakan adalah feses dan aquadest.

Prosedur Penelitian

\section{Persiapan Sampel}

Persiapan pasien: Pasien tidak dalam keadaan mengkonsumsi bismuth

Persiapan sampel: Pengambilan sampel sebaiknya dilakukan pada pagihari

Metode Pemeriksaan

Disiapkan alat dan bahan yang akan digunakan kemudian diambil sampel 
sebanyak 1 gr dengan menggunakan batang pengaduk lalu masukkan ke dalam beaker gelas. Ditambahkan aquadest sebanyak $25 \mathrm{ml}$ lalu dihomogenkan kemudian disentrifus selama 5 menit dengan $2000 \mathrm{rpm}$. Filtrat dibuang sampai yang tersisa adalah endapan. Diambil endapan dengan menggunakan pipet lalu simpan diobjek gelas dan tutup dengan cover gelass lalu diamati di mikroskop pembesaran objektif 10x

\section{Analisa Data}

Analisa data dimulai dari data primer yaitu kusioner higiene pribadi dan sanitasi lingkungan. Metode yang digunakan dalam uji validitas adalah korelasi bivariat pearson. Setelah itu dilakukan uji prasyarat analisis dengan uji normalitas dan uji linearitas. Jika kriteria pada uji prasyarat analisis sudah terpenuhi maka dilanjutkan dengan analisis korelasi untuk mengetahui seberapa erat korelasi antar variabel.

\section{HASIL DAN PEMBAHASAN}

Hasil penelitian diperoleh nilai $\mathrm{p}(0.00)<0.05$, maka hipotesis Ho ditolak jadi ada hubungan antara kebiasaan buang air besar dijamban/WC dengan kejadian helminthiasis. Hasil penelitian diperoleh nilai $\mathrm{p}(0.00)<0.05$, maka hipotesis Ho ditolak jadi ada hubungan antara kebiasaan menggunakan alas kaki dengan kejadian helminthiasis. Hasil penelitian diperoleh nilai $\mathrm{p}(0.00)<0.05$, maka hipotesis Ho ditolak jadi ada hubungan antara kepemilikan jamban dengan kejadian helminthiasis.

Perkembangan

epidemiologi menggambarkan secara spesifik interaksi manusia dengan lingkungannya yang merupakan suatu proses yang wajar yang terlaksana sejak manusia dilahirkan sampai ia meninggal dunia. Hal ini disebabkan karena manusia memerlukan daya dukung lingkungan untuk kelangsungan hidupnya (Soemirat 2000).

Kontribusi lingkungan berpengaruh pada penyakit dan sudah sejak lama diperkirakan oleh manusia.Hendrik mengemukakan bahwa lingkungan merupakan factor utama yang mempengarhu derajat kesehatan masyarakat dimana lingkungan memegang peranan penting terhadap pola penyebaran penyakit. Oleh karena itu, meskipun upaya kesehatan telah dilakukan secara maksimal tetapi bila lingkungan belum tertata dengan baik maka tidak akan menjamin peningkatan derajat kesehatan masyarakat (Depkes RI, 1999).

Higiene adalah usaha kesehatan masyarakat yang mempelajari pengaruh kondisi lingkungan terhadap kesehatan manusia, upaya pencegahan terhadap munculnya penyakit memberikan pengaruh lingkungan kesehatan serta membuat kondisi lingkungan sedemikian rupa sehingga terjamin pemeliharaan kesehatannya. Kebiasaan menggunakan alas kaki saat beraktivaitas diluar rumah dapat secara langsung mencegah terjadinya melalui soil transmitted.

Penularan melalu tanah dapat dilakukan oleh nematode usus yang memiliki siklus hidup berupa larva rhabditfoarm.Kemampuan larva tersebut menembus kulit manusia sehingga soil transmitted memiliki peranan penting dalam penyebaran helminthiasis. Helminthiasis dapat ditularkan melalu tinja dari penderita helminthiasis, Buang air besar di dalam jamban/WC akan menurunkan penularan helminthiasis. Jamban yang baik harus mempunyai syarat antara lain, tidak mengotori air permukaan, tidak mengootori air tanah,kotoran tidak boleh terbuka sehingga dapat menjadi sumber penularan yang terbawa oleh lalat untuk bertelur atau berkembang biak.

\section{KESIMPULAN}

Berdasarkan hasil penelitian dan pembahasan tentang hubungan hygiene pribadi dan sanitasi lingkungan dengan kejadian helminthiasis di Kelurahan Rappocini Kecamatan rappocini dapat ditarik kesimpulan sebagai berikut:

1. Tidak adanya korelasi antara kebiasaan mencuci tangan dengan kejadian helminthiasis

2. Adanya korelasi antara kebiasaan buang air besar dengan kejadian helminthiasis. Adanya kemungkinan menderita helminthiasis jika penderita 
memiliki kebiasaan buang air besar di halaman rumah dan bukan di wc.

3. Adanya korelasi antara kebiasaan menggunakan alas kaki dengan kejadian helminthiasis. Adanya kemungkinan menderita helminthiasis jika tanah terkontaminasi oleh helminth dari jenis Soil Transmitted Helminth (STH).

4. Adanya korelasi kepemilikan jamban dengan kejadian helminthiasis. Adanya kemungkinan penyebaran helminthiasis jika tidak adanya kepemilikan jamban sehingga penderita akan buang air besar di tempat yang tidak sesuai.

5. Tidak adanya korelasi antara ketersediaan air bersih dengan kejadian helminthiasis

6. Tidak adanya korelasi antara ketersediaan sistem pembuangan air limbah dengan kejadian helminthiasis

7. Diantara semua variable yang memiliki korelasi dengan kejadian helminthiasis maka kepemilikan jamban yang memiliki korelasi paling besar dengan kejadian helminthiasis

\section{SARAN}

Diharapkan higiene pribadi dan sanitasi lingkungan dapat lebih digalakkan ditengah masyarakat, sehingga kejadian helminthiasis dapat diminimalisir. Diharapakan peneliti selanjutnya dapat melakukan penelitian lain yang berhubungan dengan aspek social ekonomi dan status gizi masyarakat dengan kejadian helminthiasis dengan menentukan tingkat infeksi penderita helminthiasis.

DAFTAR PUSTAKA

Zulkoni, A. 2011. Parasitologi Untuk Keperawatan, Kesehatan
Masyarakat dan Teknik

Lingkungan. Yogyakarta:

Nuha Medika.

Irinato, K. 2013. Parasitologi Medis. Bandung: Alfabeta.

Gandahusada, S. 2000. Parasitologi Kedokteran Edisi Ketiga. Jakarta: Gaya Baru.

Prianto, J. 2010. Atlas Parasitologi Kedokteran. Jakarta: PT. Kompas Gramedia.

Safar, R. 2009. Parasitologi Kedokteran. Bandung: Yrama Widya.

Irianto, K. 2009. Parasitologi Untuk Paramedis dan Non Medis. Bandung: Yrama Widya.

Soedarto, Prof. 2011. Buku Ajar Parasitologi Kedokteran. Surabaya: Sagung Seto.

Natadisastra, D. 2002. Parasitologi Kedokteran. Jakarta: EGC.

Natadisastra D.1999. Bunga Rampai Entomologi Medik. Edisi 2 FK Unpad: Bagian Parasitologi

Balai Besar Laboratorium Kesehatan. 2014. Teknis pemeriksaan Nematoda Usus. Makassar

Brown, H. 1979. Dasar Parasitoilogi Klinis. PT. Gramedia, Jakarta

Gadahusada, S. Dkk. 2000. Parasitologi Kedokteran. Edisi ketiga Balai

Penerbit FKUI, Jakarta.

Sutanto, 2013. Parasitologi Kedokteran.

$\begin{array}{ll}\text { Fakultas } & \text { Kedokteran } \\ \text { Universitas } & \text { Indonesia, } \\ \text { Jakarta. } & \end{array}$

Suriptiastuti. 2006. Infeksi soiltransmitted helminth: Ascariasis, Trichiuriasis dan cacing tambang. Vol.25 No.2 : 85 